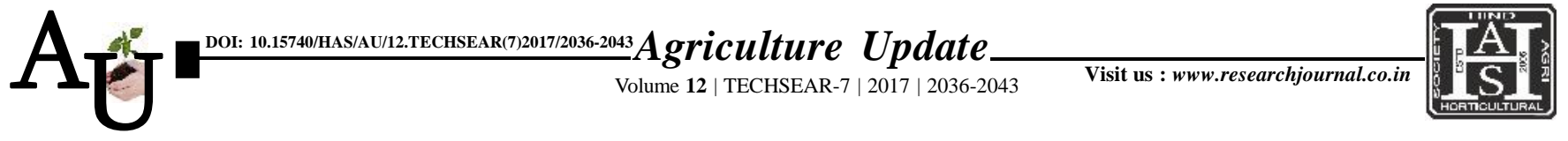

\title{
Research Article: Management practices adopted for cattle in sugarcane pockets of Nanded district
}

\author{
S.S. GHUGE, D.V. BAINWAD AND D.B. SHINDE
}

Article Chronicle:

Received :

19.07.2017;

Accepted :

03.08.2017

KeY WoRds :

Cattle, Management

practices, Sugarcane

pockets
Author for correspondence :

\section{S.S. GHUGE}

Department of Animal Husbandry and Dairy

Science, College of Agriculture, Vasantrao

Naik Marathwada Krishi

Vidyapeeth, PARBHANI (M.S.) INDIA

See end of the article for authors' affiliations
SUMMARY : The present investigation entitled Management Practices adopted for Cattle in Sugarcane Pockets of Nanded district was undertaken to study the different package of practices followed for indigenous and crossbred cattle. Twenty villages of sugarcane pockets of Nanded district were selected with the objectives to determine existing management practices. The data was collected from the 200 respondents in four sugarcane pockets. The study revealed that the indigenous cattle is mostly used for the draft purpose. The populations of female are more than that of male one. Open and kaccha housing pattern was followed in almost all cases. Additional ration for pregnant animals were given by very few number of farmers. Cent per cent farmers adopted health and sanitation measures as cleaning of milking utensils, cleaning of hands and washing of udder before milking. Vaccination schedule was followed nearly about 93.00 per cent. There was very few farmers who adopted urea treatment and silage preparation. Practices of dehorning of calf does not adopted by any farmer.

How to cite this article : Ghuge, S.S., Bainwad, D.V. and Shinde, D.B.(2017). Management practices adopted for cattle in sugarcane pockets of Nanded district. Agric. Update, 12(TECHSEAR-7) : 2036-2043; DOI: 10.15740/ HAS/AU/12.TECHSEAR(7)2017/2036-2043. 